\title{
Aggressive NK-cell leukemia
}

INSERM

\section{Source}

INSERM. (1999). Orphanet: an online rare disease and orphan drug data base. Aggressive NK-cell leukemia. ORPHA:86873

Aggressive NK-cell leukemia (ANKCL) is an extremely rare and highly aggressive neoplasm, usually manifesting in the third to fourth decade of life, affecting males and females equally, and characterized by the onset of high fever, weight loss, jaundice, skin infiltration, lymphadenopathy, hepatosplenomegaly, and severe anemia. ANKCL has a fulminant and rapidly fatal disease course with the progressive appearance of multiorgan failure and disseminated intravascular coagulation. 